\title{
The Heterogeneous Impacts of the Ratification of CEDAW on the Adoption of Violence Against Women Laws
}

\author{
Byung-Deuk Woo
}

\begin{abstract}
Even though previous literature on the impacts of the ratification of the Convention on the Elimination of All Forms of Discrimination against Women (CEDAW) has broadened our understanding of the conducive influences of CEDAW on women's rights, the impacts of the ratification of CEDAW on the adoption of women's rights laws, especially violence against women laws, based on a diffusion mechanism have not been empirically examined. Also, the heterogeneous impacts of the ratification of CEDAW on the diffusion of violence against women laws by types of violence which such laws aim to penalize has not been academically unveiled. With unprecedentedly large time-series cross-national data on 129 countries from 1908 to 2016, this article estimating pooled event history models (PEHM) with a directed dyadic setup demonstrates that the ratification of CEDAW increases the probability of adopting violence against women laws of other countries substantially. In addition, the empirical results show that the conducive influence is conspicuous related to the diffusion of laws about sexual harassment, and domestic and intimate partner violence, while the probability of adopting laws not specifying certain forms of violence against women tends to decrease with the ratification of CEDAW. Those empirical results are robust and consistent in different model specifications.
\end{abstract}

Keywords: CEDAW, Violence Against Women, Women's Rights, Pooled Event History Models

\footnotetext{
* Byung-DeukWoo (byungdeukwoo@gmail.com) received his Ph.D. degree in political science from the University of Iowa (2021). His research focuses on Comparative Politics, Women in Politics, and Political Methodology. He has published journal articles in Asian Women, PNU Journals of Women's Studies, Oughtopia, Korean Journal of Security Affairs, and Korean Journal of Defense Analysis.
} 


\section{INTRODUCTION}

After being adopted by the United Nations General Assembly on December 18, 1979, the Convention on the Elimination of All Forms of Discrimination against Women (CEDAW) within the global women's rights system has been widely spotlighted by scholars. Since CEDAW entered into force on September 3, 1981, 189 countries, except Iran, Somalia, Tonga, and Sudan, have ratified or acceded to CEDAW over decades (Vijeyarasa 2021). With the increasing number of member countries of CEDAW, a series of studies have focused on the conducive impacts of CEDAW on improving women's rights over the globe in political and societal aspects such as gender equality, women's freedom of religion and property rights, and the jurisdiction of gender (Brandt \& Kaplan 1995; Byrnes 1989; Englehart \& Miller 2014; Hellum 2021; Hill Jr 2010; Resnik 2012).

However, even though the various impacts of CEDAW have long been examined by previous studies over decades, the influence of CEDAW on the adoption of policies addressing violence against women 1 by emulating other countries has not been thoroughly examined empirically. Considering that emulating policies of neighboring countries has been recognized as one of the important mechanisms of policy adoptions (Goyal 2021; Kreitzer \& Boehmke 2016; Linos 2013; Shipan \& Volden 2008; Volden 2016) and that CEDAW has played a crucial role in dispersing women's right's agenda over the world (True 2016), such academic lacuna is unexpected. In addition, although all violence against women laws are not the same but different in terms of targeted forms of violence against women, the heterogeneous impacts of CEDAW on the adoption of violence against women according to the types of violence have not been studied.

Does the ratification of CEDAW lead countries to adopt violence against women laws of other countries with such laws? Moreover, is the influence of CEDAW on the diffusion of violence against women laws among countries heterogeneous according to the types of violence that the laws aim to penalize? With

\footnotetext{
${ }^{1}$ This article follows the United Nations' definition of violence against women: "the term violence against women means any act of gender-based violence that results in, or is likely to result in, physical, sexual, or mental harm or suffering to women, including threats of such acts, coercion or arbitrary deprivation of liberty, whether occurring in public or in private life." The forms of violence against women include trafficking of women and girls, stalking, sexual violence, sexual harassment, female genital mutilation, domestic and intimate partner violence, and child, early, and forced marriage. Thus, violence against women (VAW) is a subset of gender-based violence (GBV) and sexual and gender-based violence (SGBV). Even though the three terms are often used interchangeably, this article uses "violence against women (VAW)" instead of GBV and SGBV given that this article does not examine gender-based violence against men. For the detailed information about the definition of violence against women by the UN, please refer the following website: https://www.un.org/en/genocideprevention/documents/atrocity-crimes/Doc.21_declaration\%20elimina tion\%20vaw.pdf (Accessed on November 4, 2021).
} 
unprecedentedly large data on 129 countries from 1908 to 2016, this study estimating pooled event history models (PEHM) demonstrates that the ratification of CEDAW increases the probability of adopting laws combating violence against women substantially. In addition, the empirical results show that the conducive influence is conspicuous related to the diffusion of laws about sexual harassment, and domestic and intimate partner violence, while the probability of adopting laws without clauses indicating specific forms of violence against women tends to decrease with the ratification of CEDAW.

This article proceeds with the following order. In the next section, previous literature on the impacts of CEDAW on women's rights will be reviewed. Then, theories and hypotheses about the association between the ratification of CEDAW and the adoption of violence against women laws of other countries will be introduced. In the Empirical Analysis section, modeling strategies, variables and operationalization, and empirical results will be presented. Lastly, I conclude with the contributions of this study, the discussion about potential limitations, and the promising future directions of research on CEDAW.

\section{LITERATURE REVIEW}

Illustrated by some previous scholars as an "international bill of rights for women" (Byrnes \& Freeman 2012), CEDAW is the only international human rights treaty concentrating to deal with all forms of sex and gender-based discrimination and to establish clear obligations to improve women's rights and integrity (Hellum 2021; Hellum \& Aasen 2013). To achieve substantive gender equality, CEDAW obliges member countries to adopt "appropriate legislative and other measures, including sanctions where appropriate, prohibiting all discrimination against women" (Article 2), to ensure "the full development and advancement of women" (Article 3), to implement "temporary special measures aimed at accelerating de facto equality between men and women" (Article 4), and to modify "the social and cultural patterns of conduct of men and women with a view to achieving the elimination of prejudices" (Article 5). ${ }^{2}$

Furthermore, the committee on CEDAW composed of 23 experts has monitored the successful implementation and enactment of CEDAW in member countries. With the relatively triumphant implementation and enactment, CEDAW has been acknowledged for its level of authority and visibility as an

\footnotetext{
${ }^{2}$ For more information about the Articles, please refer the following website: https://www.ohchr.org/ en/professionalinterest/pages/cedaw.aspx (Accessed on September 4, 2020).
} 
"instrument of social transformation" (Zwingel \& Zwingel 2016). The creation of CEDAW and the monitoring committee has contentedly dispersed global norms of women's rights across the globe and urged countries to handle various disadvantages suffered by women (Vijeyarasa 2021).

In the 40th anniversary of CEDAW on 18 March 2019, the vice-chair of CEDAW, Nicole Ameline 3 , emphasized the connections between the General Recommendations of CEDAW and the 2030 Agenda in achieving gender equality and women's empowerment as follows,

“Gender equality and women's empowerment have been included as a stand-alone goal and mainstreamed in many other goals and targets of the 2030 Agenda for Sustainable Development. In this holistic view of the 2030 agenda, ending discrimination and achieving gender equality and women's empowerment is considered an important way for transforming the deeply embedded civil, political, social, economic and cultural structures that impede the participation of women and girls to development. []. There are numerous connections between the Committee's general recommendations and the 2030 Agenda […] including gender-based violence [...]. It is undeniable that women's empowerment is a key factor for stability and state building, and that women, including women victims, are the force for lasting peace."

Although violence against women was not recognized as a priority for action when CEDAW was presented to the intergovernmental meeting at Copenhagen in 1980 (Keck \& Sikkink 1998; Weldon 2006), the CEDAW committee backed by the intensified efforts of women's movements has expressed serious concerns over the problems of violence against women since the third global Women Conference held in 1985 (Qureshi 2020; Zada 2021). Through the General Recommendation No.12, CEDAW urges member countries to put their efforts to eradicate violence against women, especially domestic and intimate partner violence, and to submit periodic reports for all measures taken (McQuigg 2007). Moreover, the General Recommendation No.19 addresses the problem of violence against women more detailly and identifies that the discriminatory pattern of violence against women threatening women's enjoyment of human rights. 4

Even though some pessimistic quantitative literature argues that international

\footnotetext{
${ }^{3}$ For the full opening remarks by Nicole Ameline, please refer the following website: https://www.oh chr.org/EN/HRBodies/CEDAW/Pages/40thAnniversaryCEDAW.aspx (Accessed on September 4, 2020).

4 For the full texts of the General Recommendations, please refer the following website: ht tps://www.ohchr.org/en/hrbodies/cedaw/pages/recommendations.aspx (Accessed on September 4, 2021).
} 
human rights treaties do not essentially change human rights conditions in member countries (Hafner-Burton \& Ron 2009; Htun \& Weldon 2012), CEDAW appears to be an efficient women's rights treaty. It has been shown that CEDAW tends to have small but statistically significant positive impacts on women's rights (Gray, Kittilson, \& Sandholtz 2006; Hill Jr 2010). The various conducive impacts of CEDAW on women's rights have long been discussed and examined by previous studies (Benedek, Kisaakye, \& Oberleitner 2002; Bond 2014; Englehart \& Miller 2014; George 2020; Hellum 2021; Upreti \& Jacob 2018; Zwingel 2005).

For instance, Englehart and Miller (2014) demonstrate that the ratification of CEDAW tends to improve women's political rights and women's social rights, while Upreti and Jacob (2018) argue that the monitoring body of CEDAW has a positive impact on women's lives in the Philippines. Even earlier, Zwingel (2005) shows that the creation of CEDAW has played an important role in making a global consensus on the importance of gender equality. More interestingly, she finds that the creation of CEDAW has motivated transnational non-governmental organizations (NGOs) to promote women's rights. Recently, George (2020) unveils non-negligible impacts of the ratification of CEDAW on shaping social and political discourse about future legal and policy reforms eliminating and preventing discrimination against women, by analyzing Al-Anba articles in Kuwait from 2006 to 2010.

Likewise, even though CEDAW is a static document not changed since its adoption in 1979, the positive impacts of CEDAW have been continuously supported by scholars. However, there are still rooms to be improved.

First, the legal reforms especially related to violence against women have not been empirically examined with time-series cross-national data thoroughly. Previous studies supporting the positive and visible influence of the ratification of CEDAW have largely relied on small-N comparative and case studies (as an exception, see Hunt and Gruszczynski (2019)), which approaches have a limitation on testing the generalizability of the findings. Even though the issue of violence against women was not discussed at the beginning of the CEDAW, this academic lacuna is surprising given that the CEDAW committee has been to interpret CEDAW in a manner as to encompass the issue of violence against women (McQuigg 2017). Moreover, member states have shown a high degree of compliance to the CEDAW committee's General Recommendations mentioning the issues of violence against women such as No.12 and No.19 (Englehart 2014).

Second, even though the diffusion mechanism among countries has been regarded as an important way for a country to promote legal reforms, the impacts of the ratification of CEDAW on the adoption of women's rights laws, especially violence against women laws, based on the diffusion mechanism have not been 
empirically examined. Lastly, even though the CEDAW committee has expressed its concern on certain forms of violence against women including trafficking, domestic and intimate partner violence, and sexual harassment, the heterogeneous impacts of the ratification of CEDAW have been academically unveiled.

\section{THEORY AND HYPOTHESIS}

Focusing on violence against women laws which have been less examined compared to other women's rights laws, this article with unprecedentedly large time-series cross-national data on 129 countries aims to explore the impacts of the ratification of CEDAW on the diffusion of violence against women laws across countries. In addition, this article examines the heterogeneous impacts of the ratification of CEDAW on the adoption of violence against women laws according to the types of violence which the laws aim to penalize.

This article expects that the influence of the ratification of CEDAW on the diffusion of violence against women laws across countries is substantial. This expectation is rooted in the effectiveness of CEDAW in promoting the individual countries' legal reforms addressing violence against women. The committee of CEDAW is created "for the purpose of considering progress made in the implementation of the present Convention" (Article No.17). When the committee suspects any violation of the articles of the CEDAW by member countries, it delivers recommendations to the countries to ensure the end of the violation and to introduce legal reforms in order to prevent such violation from reoccurring. Although the acceptance of the recommendations from the CEDAW committee is not legally required (Evatt 2002), it has been regarded that the CEDAW's jurisprudence along with its monitoring body is the authoritative one (Nguyen 2014). For instance, conducting a case study on Spain, Stoffels (2019) demonstrates that the legal and juridical force of CEDAW's guarantee mechanisms leads the Spanish Government to take public policy reform improving the rights of girls.

In addition to the recommendations, the international pressure imposed by CEDAW on individual member countries to follow CEDAW's objectives of the elimination of all forms of discrimination against women can lead the countries to take legal changes aiming to penalize violence against women. Even though CEDAW at first did not directly prohibit violence against women, it continuously provides a gender specific framework on the elimination of all forms of discrimination against women which includes the issue of violence against 
women (McQuigg 2017; Simonovic 2014). CEDAW envisages the obligation of member countries to submit a report every four years on how they pursue substantive provisions of CEDAW. The reports should include information about the countries' legal measures to implement the provisions and any problems faced by countries to achieve such goals. 5 By drafting and preparing the reports, member countries enable to reflect their legislations for the purpose of following the substantive provisions of CEDAW. The failure to demonstrate the commitment and compliance to the recommendations from CEDAW places more pressure on member countries to follow their international duties under CEDAW by taking further steps to handle the problem of violence against women (Farhoumand-Sims 2009; McQuigg 2007). The influence of the international pressure from CEDAW has been supported by some of the previous case studies (Shinohara 2008; Stoffels 2019; Weiss 2003).

The ratification of CEDAW can also engender domestic pressure on the government to handle the issue of violence against women. The crucial work from Simmons (2009) empirically demonstrates that even if international organizations have a restricted ability to enforce treaty regimes such as CEDAW, the ratification of human rights treaties provides a compelling tool for domestic political discourse. To be specific, domestic political actors supporting to the ratified human rights treaties are able to plead to the authority of the international treaty to pressure the government to improve practices for human rights (also see, Creamer and Simmons (2018) and Creamer and Simmons (2020)). In terms of CEDAW, Simmons (2009) provides evidence that the ratification of CEDAW and the engendered women's organizations increase women's rights with regard to women's access to formal education and raise public attention on the issue of violence against women.

Under both international and domestic pressure generated from the ratification of CEDAW, member countries are likely to emulate other countries' laws and policies to promote legal reforms and policy innovations in order to meet the requirements from the committee of CEDAW. By relying on emulating other countries' violence against women laws, member countries can overcome their informatic limitations about adopting new laws concerning violence against women. Given that the emulation has been studied as one of the mechanisms of adoption and diffusion of laws and policies (Boehmke 2009b; Fourie 2014; Meseguer 2005; Volden 2016), I expect that the ratification of CEDAW leads countries more likely to adopt violence against women laws of another countries.

\footnotetext{
${ }^{5}$ For more information, please see the United Nations Human Rights Treaty System at the following link: https://www.ohchr.org/documents/publications/factsheet3orev1.pdf(Accessed on September 4, 2021).
} 
Hypothesis 1: The ratification of CEDAW leads countries more likely to adopt violence against women laws of other countries, while all other things being equal.

Moreover, this article also hypothesizes the potential heterogeneous impacts of CEDAW on the adoption of violence against women laws by types of violence that such laws aim to penalize. This expectation is based on the fact that the General Recommendations of CEDAW has stressed the need to eradicate certain forms of violence such as domestic and intimate partner violence, sexual harassment, and trafficking, and the high degree of compliance of member countries to the recommendations (Englehart 2014). The concerns from CEDAW have been expressed by its general recommendation No.19 adopted in 1992, and No.35 updated in 2017. First of all, CEDAW has urged countries to take legal actions addressing domestic and intimate partner violence. In the recommendation No.19, it says that member countries "should establish or support services for victims of family violence", adopt legislation to provide services for "the safety and security of victims of family violence, including refuges, counselling and rehabilitation programmes", and introduce other effective legal measures to protect women against "violence and abuse in the family".

Second, sexual harassment has also been focused on by CEDAW over decades. In the recommendation No.19, CEDAW delivers its decision to allocate part of articles to "the sexual harassment and exploitation of women", and expresses significant concerns of sexual violence in Article No.11 as below.

\begin{abstract}
"Sexual harassment includes such unwelcome sexually determined behavior as physical contact and advances, sexually coloured remarks, showing pornography and sexual demands, whether by words or actions. Such conduct can be humiliating and may constitute a health and safety problem; it is discriminatory when the woman has reasonable ground to believe that her objection would disadvantage her in connection with her employment, including recruitment or promotion, or when it creates a hostile working environment."
\end{abstract}

In addition, as specific recommendations, CEDAW urges member countries to provide information on "sexual harassment, and on measures to protect women from sexual harassment".

Even though relatively less discussed than domestic and intimate partner violence, and sexual harassment, trafficking also has been pointed out by CEDAW in the recommendations as one of the forms of violence that should be handled immediately. In the General Recommendation No.19, CEDAW mentioned that "specific preventive and punitive measures are necessary to overcome 
trafficking and sexual exploitation" and required members of CEDAW to report all measures taken by them to protect "women engaged in prostitution or subject to trafficking and other forms of sexual exploitation". Moreover, in Article 6 of CEDAW, CEDAW emphasizes the problem of trafficking of women as "States Parties shall take all appropriate measures, including legislation, to suppress all forms of traffic in women and exploitation of prostitution of women."

On the contrary, CEDAW urges countries only with violence against women laws concerning comprehensive forms of violence against women and without specific provisions indicating which behaviors should be regarded as violence against women to revise or to modify or revise the clauses. For instance, among countries located in North Africa and the Middle East, Egypt, Iraq, Qatar, and United Arab Emirates are typical examples. The committee of CEDAW has continuously urged Egypt and Iraqi to revise clauses related to violence against women in the Egyptian Penal Code and Iraqi Family Law and to specify forms of violence against women in the legislations. Even though the Egypt has comprehensive violence against women laws, the committee mentioned that the Egyptian Panel Code lacks a holistic approach to the prevention and elimination of specific forms of violence against women such as domestic and intimate partner violence, and martial rape. In addition, even if the Iraqi Family Law issued in 1959 has been considered among the best laws in North Africa and the Middle East, the problem of the child, early, and forced marriage, and domestic violence are not legally recognized under the Iraqi Law. Similarly, the penal codes of Qatar and of the United Arab Emirates have been criticized due to their lack of detailed definitions of the forms of violence against women by the committee of CEDAW. 6

Therefore, considering the CEDAW General Recommendations' exclusive emphasis on the three forms of violence against women, and the CEDAW's focus on both the problem of all forms of traffic in women and the introduction of clauses indicating certain forms of violence against women rather than only comprehensive provisions penalizing violence against women, I expect that the ratification of CEDAW leads countries more likely to adopt violence against women laws penalizing domestic and intimate partner violence, sexual harassment, and trafficking, and less likely to adopt such laws not specifying

\footnotetext{
${ }^{6}$ For more information on the periodic reports, please refer the following links: https://www.un.org/ womenwatch/daw/cedaw/cedaw25years/content/english/CONCLUDING_COMMENTS/Egypt/Egypt-CO -3_\%20CO-4-5.pdf for Egypt, https://www.refworld.org/publisher,CEDAW,,IRQ 56e7b8314,o.html for Iraq, https://www.refworld.org/publisher,CEDAW,,QAT,52dd18bf4,o.html for Qatar, and https://www.ref world.org/publisher,CEDAW,STATEPARTIESREP,ARE,4970841f2,o.html for the United Arab Emirates (Accessed on November 24, 2021).
} 
them.

Hypothesis 2: The ratification of CEDAW leads countries less likely to adopt violence against women laws not specifying certain forms of violence, while all other things being equal.

Hypothesis 3: The ratification of CEDAW leads countries to more likely to adopt violence against women laws specifying certain forms of violence, while all other things being equal.

\section{EMPIRICAL ANALYSIS}

To test the hypotheses presented in the last section, this study conducted a time-series cross-national analysis with unprecedentedly large data on laws addressing violence against women of 129 countries from 1908 to 2016. This empirical approach allows us to check the generalizability of empirical results and to accurately estimate the influence of CEDAW on the diffusion of violence against women laws over the globe. First, model specifications used in the empirical analysis will be explained. Then, variables with information about data source and operationalization will be explained and empirical results will be presented.

\section{MODEL SPECIFICATIONS}

This paper aims to evaluate the influence of the ratification of CEDAW on the adoption of laws addressing violence against women with the consideration of the diffusion mechanism. In addition, the heterogeneous impacts of CEDAW will be examined across the types of violence that each law penalizes.

To achieve both goals, I estimate a pooled event history analysis (PEHA) recently developed by Kreitzer and Boehmke (2016) with a directed dyadic setup. Event history analysis (EHA) is one of the standard approaches to modeling diffusion mechanisms because it makes possible for scholars to account for internal and external factors of the adoption of policies or laws (Berry \& Berry 1990; Pacheco 2012; Volden 2006). However, the standard EHA cannot model the heterogeneous impacts of explanatory variables on the adoption of policies and laws with different components or aspects.

On the contrary, PEHA allows us to examine the effects of the ratification of 
CEDAW across violence against women laws across multiple types of violence penalized by such laws through stacking the data and estimating beta coefficients in a single model specification (Kreitzer \& Boehmke 2016; Makse \& Volden 2011). With policies or laws as the group level, a discrete pooled event history model estimated based on a multilevel strategy with policy or law random effect enables both the estimated intercept and coefficients of explanatory variables to vary across policies or laws (Kreitzer and Boehmke, 2016, 124p). The inclusion of the policy or law random effect makes it possible not to make a strict assumption that the pooled types of laws or policies are very similar to be regarded as the same things (Boehmke 2009a). In my case, the estimated coefficients of the ratification of CEDAW are allowed to vary by laws with different target forms of violence against women.

Moreover, estimating pooled event history models is more parsimonious in analytical sense compared to several separate event history models by the laws with different target forms of violence against women. As trade-off of model parsimony, the use of PEHA prevents me from unveiling different set of independent variables which can have idiosyncratic impacts by different types of laws according to the various forms of violence against women (Kreitzer \& Boehmke 2016). However, given that the aim of this article is to examine the potential heterogeneity of one independent, the ratification of CEDAW, the application of PEHA is more appropriate than the use of several separate event history models.

In addition to PEHA, this article apply a directed dyadic setup where each country is, in turn, the potential "receiver (country $\left.)_{i}\right)$ " and "sender (country $)_{j}$ )" of the adoption of laws addressing violence against women (Gilardi 2010). To be specific, country ${ }_{j}$ is composed of countries that have already adopted the laws by the forms of violence against women, while countries without the laws

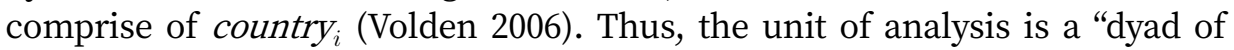
countries ( country $_{i}$ and country $y_{j}$ )-year $(t)$-laws by types of violence $(l)$." Below is the methodological expression of PEHM in the directed dyadic setup based on the notation from Kreitzer and Boehmke (2016) and Gilardi and Füglister (2008).

$$
\begin{aligned}
& Y_{i j t l}=\left\{\begin{array}{lll}
0 & \text { if } & Y_{i j l}^{*} \leq 0 \\
1 & \text { if } & Y_{j j l}^{*}>0
\end{array}\right. \\
& Y_{i j t l}^{*}=\left(\beta_{00}+\mu_{0 l}\right)+\left(\beta_{10}+\mu_{11}\right) \times C E D A W \text { Ratification }+\epsilon_{i j t t}
\end{aligned}
$$

where $Y_{i j t l}$ is the country's adoption of laws addressing violence against women according to the types of violence by country $y_{i}$ emulating country in a year $r, Y_{i j t l}^{*}$ 
is a latent variable, $B_{00}$ is the grand mean of the model, $\mu_{0 l}$ denotes the residual of types of violence level variation in the intercept (random intercept), $\beta_{10}$ represents the fixed part of the influence of the ratification of CEDAW, and $\mu_{1 l}$ stands for the residual of types of violence level variation in the coefficient of CEDAW ratification (random slope). It is assumed that the residuals, $\mu_{0 l}, \mu_{1 l}$, and $\epsilon_{i l t}$ have 0 expected values and constant variance, and $\mu_{0 l}$ and $\mu_{1 l}$ are not correlated to $\epsilon_{i j l t}$. A series of control variables at the individual level (country $y_{i}$ ) and at the dyadic level between country $_{i}$ and country ${ }_{j}$ can be additionally included.

\section{VARIABLES}

\section{DEPENDENT VARIABLE}

As a dependent variable, the country ${ }_{i}$ 's adoption of laws addressing violence against women by emulating country ${ }_{j}$ is used. To be specific, when country ${ }_{i}$ adopts a law that country ${ }_{j}$ has already adopted, I code the dependent variable as one; otherwise, zero is assigned.

To investigate the heterogeneous impacts of the ratification of CEDAW, laws about violence against women are classified into eight categories: 1 ) laws not specifying certain forms of violence, 2) trafficking, 3) stalking, 4) sexual violence, 5) sexual harassment, 6) female genital mutilation (FGM), 7) domestic and intimate partner violence, and 8) child, early, and forced marriage. Dyad-year observations are pooled by the eight forms of violence, which enables me to conduct empirical analysis through pooled event history models and to estimate the heterogeneous impacts of the ratification of CEDAW on the introduction of laws according to the eight types of violence.

Not to arbitrarily classify laws into the eight categories, this article follows the classification the Global Database on Violence against Women developed by UN Women (n.d.). The Global Database on Violence against Women provides detailed information about laws about violence against women with brief descriptions and primary sources of each law and tracks every legal reform in 194 countries by the eight forms of violence from 1908 when Japan first adopted the Penal Code of 1908 with the issue of violence against women to 2016. The broad coverage of the database makes me possible to fully examine the heterogenous impacts of CEDAW on the introduction of violence against women laws from "the start". Even though the database also provides information about laws concerning "Other Forms of Violence" including feminicide, this category is not used because there are no clear demarcations among the "Other Forms." 
It should be noted that the Global Database on Violence against Women provides information on laws focusing on the problem of violence against women itself. For instance, laws about sexual harassment in the realm of labor laws are not included in the database, while the information about criminal laws, acts, or codes concerning the eight forms of violence against women are provided. Given that the Global Database does not provide information in a dyadic setup but present it in a country-year observation format, I gather the original data from the database and transform it into a dyadic setup.

\section{INDEPENDENT VARIABLE}

To examine the influence of CEDAW on the adoption of policies addressing violence against women, this article relies on a binary independent variable indicating whether a country $y_{i}$ serves as a member of CEDAW. If a country ratified CEDAW in 1985, 1 is assigned to the country after 1985. Otherwise, 0 is assigned.

As Figure 1 presented, the number of countries that ratified CEDAW has dramatically increased since its adoption by the United Nations General Assembly in 1979. Starting from 10 countries ratifying CEDAW in 1980, the number was over 100, and it reached 189 in 2015. Compared to any other international treaties aiming to improve women's rights, the membership of CEDAW has enlarged faster. The variations that exist in the independent variable enable me to estimate the influence of the ratification of CEDAW on the adoption of policies targeting violence against women through policy diffusion.

Figure 1. Number of Countries Ratified CEDAW from 1980 to 2020

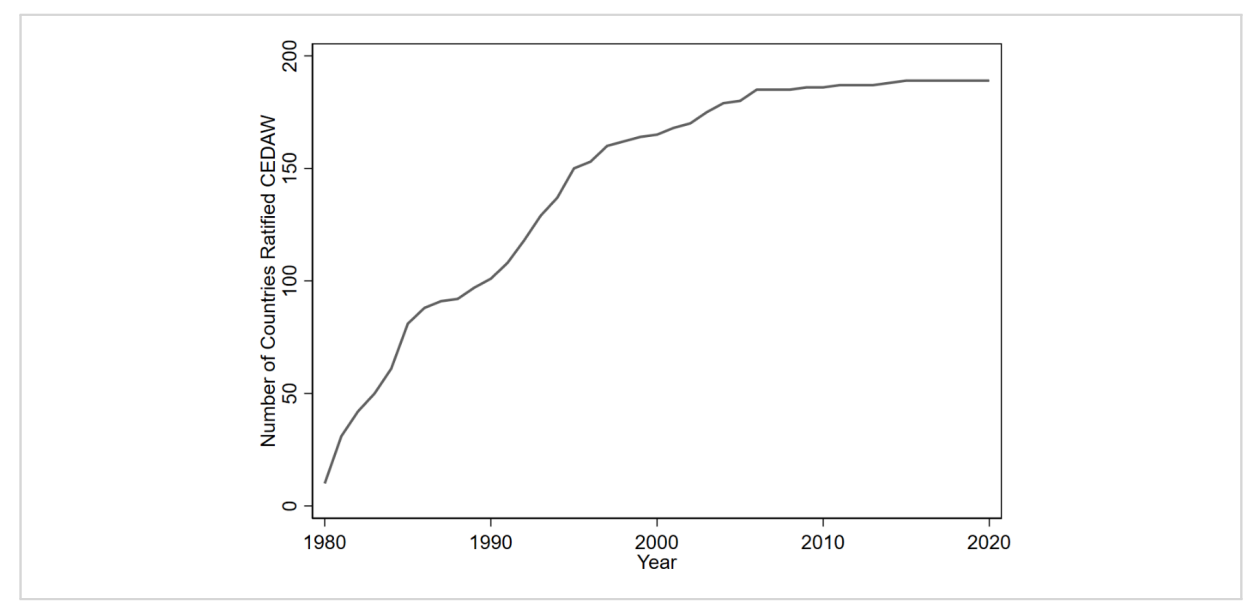

Note: The information about the membership of each country to CEDAW is from the United Nations Human Rights Office of the High Commissioner. 


\section{CONTROL VARIABLES}

To prevent the empirical results be biased due to the exclusion of relevant variables, I include a series of control variables that have been regarded as potential determinants of the adoption and implementation of policies combating violence against women.

First, the levels of economic development and democracy of an individual country $_{i}$ are controlled to parcel out the expected positive impacts of those two factors on the diffusion of laws addressing violence against women. This decision is based on the previous studies demonstrating that countries with higher levels of economic development and democracy tend to promote policies for women's rights (e.g., see Kalandadze and Orenstein (2009), Haggard and Kaufman (2008), Inglehart, Norris, and Ronald (2003), and Wilensky (1974)). To measure the influence of those two factors, GDP per capita and Polity Score respectively based on the Maddison Project Database (Bolt, Robert Inklaar, jong, \& Zaden 2018) and Polity IV dataset (Marshall 2017b) are employed. Also, given that policy emulation tends to occur among politically and economically similar countries (Baldwin, Carley, \& Nicholson-Crotty 2019; Meseguer \& Gilardi 2009), I control the absolute differences in GDP per capita and Polity Score between country $_{i}$ and country ${ }_{j}$ based on the rationale that countries tend to emulate laws in other countries with similar levels of economic and democracy.

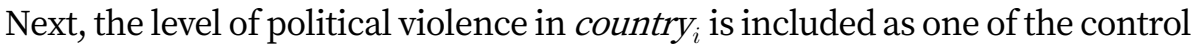
variables. Some previous studies demonstrate that political violence is not associated with the probability of adopting laws addressing violence against women (Woo 2021). However, the level of political violence still can be used as a good proxy to measure the varying rate of violence against women, given that there are no reliable cross-national data on the statistics of violence against women (Htun \& Weldon 2012). A large number of studies demonstrate that the occurrences of various types of political violence such as civil conflicts and interstate war are positively associated with a higher rate of violence against women (Swaine 2018; True 2018). Therefore, I control the level of political violence by using the "total summed magnitudes of all societal and interstate MEPV score" in the Major Episodes of Political Violence (MEPV) database (Marshall 2017a).

Also, the colonial heritage of each country ${ }_{i}$ is taken into account. It has been argued that countries with colonial heritage tend to suffer from poor human rights including threatened women's integrity (Carey 2002; Oludare 2020). For instance, Oludare (2020) demonstrated that African countries with customary laws rooted in colonial heritage are likely to discount and downgrade women on various issues such as marriage, divorce, and female sexuality. Thus, rather than 
taking risks of the omitted variable bias (OVB), I control the colonial heritage using a binary variable: 1 indicates that a country ${ }_{i}$ has a colonial heritage, 0 otherwise.

In addition, the influences of the two women-related variables, the percentage of women in parliaments, and women's participation in civil society organizations in country $_{i}$, are parceled out. Some previous studies on gender and politics have argued that the improved women's descriptive representation in legislative branches tends to lead countries to adopt policies to protect women's rights (Betz, Fortunato, \& O’BRIEN 2021; Reingold 2008; Reingold, Kreitzer, Osborn, \& Swers 2021; Woo 2021), while other studies have emphasized the importance of women's civil society participation in policy changes for women (Hasunuma 2019; O'Hara \& Clement 2018). Therefore, rather than disregarding this literature, this study controls the two women-related factors. The Inter-Parliamentary Union (IPU) database and the index for women's participation in civil society organizations from the Variety of Democracy dataset (Coppedge et al. 2018) are used to control the expected positive influence of the two factors on the diffusion of laws addressing violence against women.

The percentage of countries ratifying CEDAW is also controlled. Individual countries' behaviors to promote women's rights are likely to be facilitated by the proliferation of global norms about women's rights. It is because individual countries tend to follow international women's rights norms because of the pressure of being accused of violation of such norms. Moreover, a strong linkage between domestic and transnational actors generated from the dispersion of global norms about violence against women can raise moral consciousness, support domestic movements supporting women's rights, and challenge norm-violating governmental behaviors (Gilardi 2012). Thus, I control the influence of global norms of women's rights by using the percentage of countries ratifying CEDAW to take the conducive impacts of the proliferation of women's rights norms into account.

I control the influence of country's legal system. This decision is based on previous studies arguing that the probability of introducing new policies and laws fundamentally depends on legal systems, because legal processes of adopting policies are different by legal systems (Alter 2000; Herawan \& Sihotang 2021). Therefore, to parcel out the potential influence of legal systems on the probability of adopting laws about violence against women, I use the legal origin variable developed by Teorell et al. (2018). It is a categorical variable indicating each country' $_{i}$ ' legal systems: 1-English Common Law, 2-French Commercial Code, 3-Socialist/Communist Laws, 4-German Commercial Code, and 5Scandinavian Commercial Code. 
Lastly, I include time polynomials to control the varying time-specific effects on the diffusion of policies addressing violence against women. The inclusion of time polynomials is one of the most efficient ways to parcel out the impacts of the unobserved time dependence (Carter \& Signorino 2010).

Table 1. Descriptive Statistics

\begin{tabular}{|c|c|c|c|c|}
\hline Variable & Mean & Std. dev. & Min & Max \\
\hline \multicolumn{5}{|l|}{ Dependent Variable } \\
\hline $\begin{array}{l}\text { Violence Against Women } \\
\text { - Policy Adoption }\end{array}$ & 0.050 & 0.219 & 0 & 1 \\
\hline \multicolumn{5}{|l|}{ Independent Variable } \\
\hline CEDAW Ratification & 0.901 & 0.299 & 0 & 1 \\
\hline \multicolumn{5}{|l|}{ Control Variables } \\
\hline GDP per capita & 1.476 & 1.862 & 0.013 & 22.072 \\
\hline Polity 2 & 3.358 & 6.647 & -10 & 10 \\
\hline Level of Violence (MEPV) & 0.604 & 1.535 & 0 & 14 \\
\hline Colonial Heritage & 0.702 & 0.458 & 0 & 1 \\
\hline Women in Parliaments (\%) & 14.634 & 10.963 & 0.000 & 63.800 \\
\hline Women's CSO Participation & 1.085 & 0.940 & -3.499 & 3.238 \\
\hline CEDAW (\%) & 88.039 & 16.358 & 0.000 & 95.897 \\
\hline Diff. GDP per capita & 1.755 & 1.707 & 0.000 & 21.185 \\
\hline Diff. Polity 2 & 6.712 & 5.962 & 0 & 20 \\
\hline \multicolumn{5}{|l|}{ Legal Systems } \\
\hline English Common Law & 0.293 & 0.455 & 0 & 1 \\
\hline French Commercial Code & 0.538 & 0.499 & 0 & 1 \\
\hline Socialist/Communist Laws & 0.097 & 0.296 & 0 & 1 \\
\hline German Commercial Code & 0.040 & 0.196 & 0 & 1 \\
\hline Scandinavian Commercial Code & 0.032 & 0.176 & 0 & 1 \\
\hline
\end{tabular}

Table 1 presents descriptive statistics for all variables used in empirical analysis in this article except time polynomials. The total number of dyad-year observations of the eight types of violence against women is 113,065. It should be noted that if a country $y_{j}$ does not have laws addressing violence against women in certain years, the dyad-year observations with the country $_{j}$ are not included in samples in order to prevent estimated coefficients from being biased because of the inclusion of observations not in the risk set (Boehmke 2009b). 


\section{RESULTS}

Table 2. Estimations from Pooled Event History Models

\begin{tabular}{|c|c|c|c|c|}
\hline & Model 1 & Model 2 & Model 3 & Model 4 \\
\hline \multicolumn{5}{|l|}{ Independent Variable } \\
\hline \multirow[t]{2}{*}{ CEDAW Ratification } & $1.351^{* * *}$ & $0.587^{* * *}$ & $0.501^{* * *}$ & $0.780^{* * *}$ \\
\hline & $(0.080)$ & $(0.088)$ & $(0.087)$ & $(0.226)$ \\
\hline \multicolumn{5}{|l|}{ Control Variables } \\
\hline \multirow[t]{2}{*}{ GDP per capita } & & -0.006 & 0.006 & 0.006 \\
\hline & & $(0.013)$ & $(0.013)$ & $(0.013)$ \\
\hline \multirow[t]{2}{*}{ Polity 2} & & $0.028^{* * *}$ & $0.027^{* * *}$ & $0.027^{* * *}$ \\
\hline & & $(0.004)$ & $(0.004)$ & $(0.004)$ \\
\hline \multirow[t]{2}{*}{ Level of Violence (MEPV) } & & $0.087^{* * *}$ & $0.093^{* * *}$ & $0.094^{* * *}$ \\
\hline & & $(0.010)$ & $(0.010)$ & $(0.010)$ \\
\hline \multirow[t]{2}{*}{ Colonial Heritage } & & $-0.109^{*}$ & -0.024 & -0.02 \\
\hline & & $(0.044)$ & $(0.045)$ & $(0.045)$ \\
\hline \multirow[t]{2}{*}{ Women in Parliaments (\%) } & & $0.004^{*}$ & $0.011^{* * *}$ & $0.011^{* * *}$ \\
\hline & & $(0.002)$ & $(0.002)$ & $(0.002)$ \\
\hline \multirow[t]{2}{*}{ Women's CSO Participation } & & $0.283^{* * *}$ & $0.256^{* * *}$ & $0.256^{* * *}$ \\
\hline & & $(0.024)$ & $(0.024)$ & $(0.024)$ \\
\hline \multirow[t]{2}{*}{ CEDAW (\%) } & & $0.052^{* * *}$ & $0.163^{* * *}$ & $0.164^{* * *}$ \\
\hline & & $(0.004)$ & $(0.007)$ & $(0.007)$ \\
\hline \multirow[t]{2}{*}{ Diff. GDP per capita } & & -0.008 & -0.001 & -0.002 \\
\hline & & $(0.010)$ & $(0.010)$ & $(0.010)$ \\
\hline \multirow[t]{2}{*}{ Diff. Polity 2} & & -0.001 & -0.004 & -0.004 \\
\hline & & $(0.003)$ & $(0.003)$ & $(0.003)$ \\
\hline \multirow[t]{2}{*}{ Constant } & $-4.209 * * *$ & $-4.725^{* * *}$ & $-7.613^{* * *}$ & $-5.903^{* * *}$ \\
\hline & $(0.079)$ & $(0.256)$ & (1.318) & (1.653) \\
\hline \multirow[t]{2}{*}{$\operatorname{var}($ constant) } & & & $12.217^{*}$ & $24.208^{*}$ \\
\hline & & & (6.193) & (11.209) \\
\hline \multirow[t]{2}{*}{$\operatorname{var(CEDAW~Ratification)~}$} & & & & $0.416^{*}$ \\
\hline & & & & $(0.199)$ \\
\hline Legal System Dummy & No & Yes & Yes & Yes \\
\hline Time Polynomials & No & Yes & Yes & Yes \\
\hline Number of Observations & 113065 & 113065 & 113065 & 113065 \\
\hline AIC & 44686.768 & 42333.966 & 41306.106 & 41196.449 \\
\hline $\mathrm{BIC}$ & 44706.040 & 42517.045 & 41498.820 & 41398.799 \\
\hline Chi-Square Statistics & 285.984 & 2238.946 & 1962.967 & 1909.990 \\
\hline Log Likelihood & -22341.384 & -21147.983 & -20633.053 & -20577.224 \\
\hline
\end{tabular}

Note: ${ }^{*} p<0.05,{ }^{* *} p<0.01,{ }^{* * *} p<0.001$. Robust standard errors in parentheses. Akaike Information Criterion $(\mathrm{AIC})$, Bayesian Information Criterion (BIC), and Log-Likelihood are presented for model comparisons. 
Table 2 shows the estimations from four Pooled Event History Models. Given that time-series cross-national data are used, robust standard errors are estimated instead of normal standard errors to handle potential heteroskedasticity. I conduct the variation inflation factor tests to examine whether there is problematic multicollinearity among explanatory variables. Across all models, the individual VIFs of independent and control variables except time polynomials are less than 4, indicating there is no multicollinearity problem in the four models (for more information about interpreting VIFs, see Hair (2009)). The high multicollinearity among time polynomials has no adverse consequences (Allison 2012).

Across the four models in Table 2, the independent variable is statistically significant at the level of $\mathrm{p}<0.001$. It indicates that if a country has a membership of CEDAW by ratifying it, the country is more likely to adopt laws addressing violence against women by emulating other countries with such laws. To be specific, the estimated coefficient of CEDAW Ratification is 0.780 , meaning that the ratification of CEDAW increases the log-odds of adopting laws about violence against women by 0.780 on average across the eight types of violence.

Turning to control variables, most of the control variables, including the level of democracy and political violence, the two women-related variables, and the percentage of countries ratifying CEDAW, are statistically significant at the level of $p<0.05$ with the expected directions. Those results are consistent with previous literature on those factors for improving women's rights. In addition, although the estimated coefficient of colonial heritage is not statistically significant in Model 3 and Model 4, it has a statistically significant relationship with the dependent variable at the level of $\mathrm{p}<0.05$, providing partial supports for the claim that countries with the historical experience under colonization are less likely to promote minority rights.

Some of the control variables, however, are not statistically significant at any level of a p-value. First, GDP per capita is not associated with the adoption of laws concerning violence against women. Even though this result does not support the argument from a branch of a modernization theory that a higher level of economic developments makes countries promote women's rights (e.g., see Inglehart (1997)), it is in the line with some previous studies find null effects of GDP per capita on women's rights (Htun \& Weldon 2012). Second, the differences in GDP per capita and Polity 2 between country $_{i}$ and country $y_{i}$ are neither statistically significant. It indicates that intra-county factors such as $C E D A W$ Ratification play more crucial roles in determining the probability of adopting laws about violence against women.

Related to the random effects of $C E D A W$ Ratification, the results from Model 
4 demonstrate that the estimated coefficient of $\operatorname{var}(C E D A W$ Ratification) is statistically significant at the level of $\mathrm{p}<0.05$. It means that there is a statistically significant variation around the effect of CEDAW Ratification, supporting my argument that the ratification of CEDAW has varying effects on the diffusion of laws by types of violence. Considering that Model 4 is the best model specification in terms of the AICs and BICs in Table 2, it is better to examine the influence of CEDAW Ratification by the types of violence more exactly.

Figure 2. Heterogenous Impacts of CEDAW according to types of violence

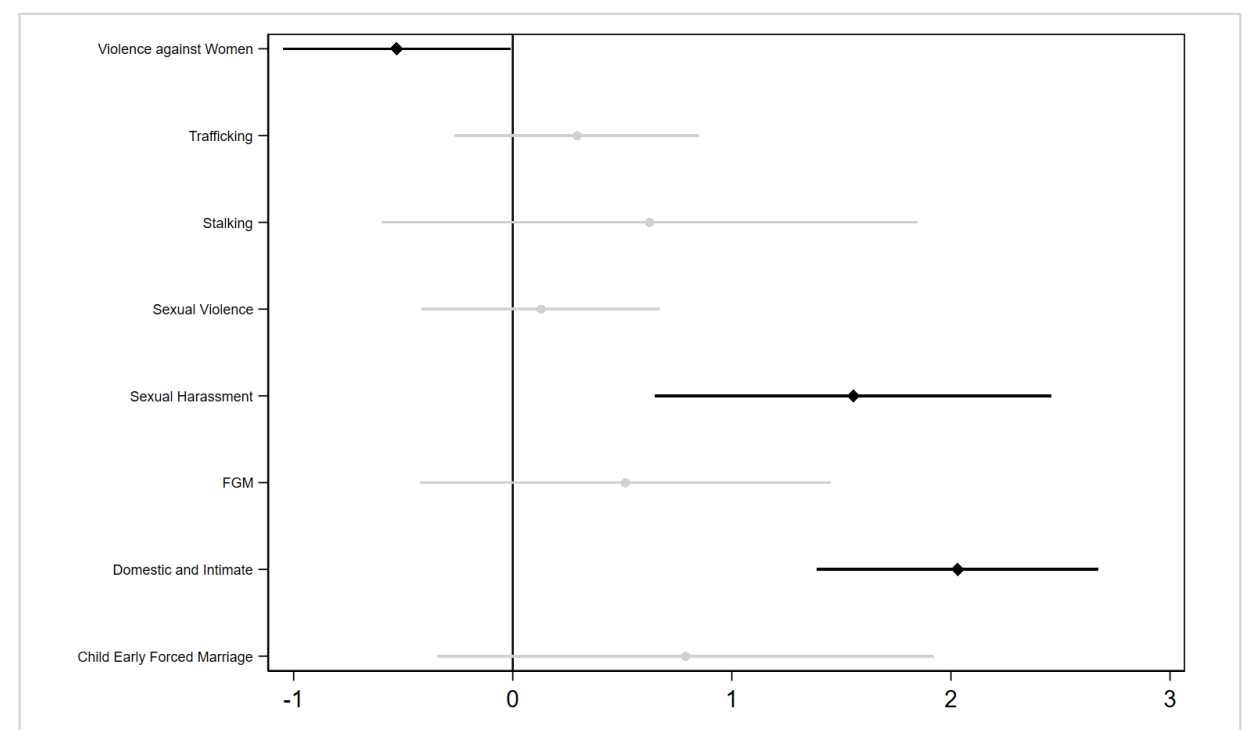

Note: $\mathrm{X}$-axis indicates the combined fixed and random effects for the influence of CEDAW Ratification on the log-odds of the adoption of laws about violence against women. The horizontal lines represent a 95\% confidence interval based on the standard errors of random and fixed effects. Black lines mean that they are statistically different from zero at the level of $p<0.05$, while gray lines mean that they are not statistically different from zero.

To visualize the varying effects of $C E D A W$ ratification by the types of violence, I construct a figure presenting the combined fixed and random effects for the influence of CEDAW Ratification on the log-odds of the adoption of laws about violence against women across the eight different types of violence (see Table A.1 in Appendix for the detailed information on the result that Figure 2 is based on). There is a great degree of heterogeneous impacts of CEDAW Ratification, with effects ranging from -0.5 to more than 2 . This result reflects the non-negligible standard deviation for the random coefficient on CEDAW Ratification in Model 
4 recovered in the multilevel model estimates. To facilitate interpretation, I plot cases that are statistically significant at the level of $\mathrm{p}<0.05$ in black, while cases that are not significant in gray.

Figure 2 demonstrates that the ratification of CEDAW tends to decrease the probability of adopting laws addressing violence against women without certain terms specifying which criminal behaviors will be penalized by the laws. On the contrary, countries ratifying CEDAW are more likely to adopt laws targeting sexual harassment, and domestic and intimate partner violence by emulating other countries. In addition, the ratification of CEDAW has not a statistically significant relationship with the adoption of laws concerning trafficking, stalking, sexual violence, FGM, and child, early, and forced marriage.

This result provides empirical evidence supporting the conducive impacts of CEDAW on the diffusion of laws addressing sexual harassment, and domestic and intimate partner violence. Moreover, the result also supports the deterrent effects on the adoption of laws not clarifying specific forms of violence against women. To be specific, the estimated coefficients of CEDAW Ratification are 1.554 and 2.031 related to the adoption of laws about sexual harassment, and domestic and intimate partner violence respectively. On the contrary, the estimated coefficient is -0.531 concerning laws without a specification of criminal behaviors, meaning that the ratification of CEDAW decreases the log-odds of adopting such laws by -0.531 .

Figure 3. Predicted probabilities of the Adoption of Violence Against Women Laws by Types of Violence

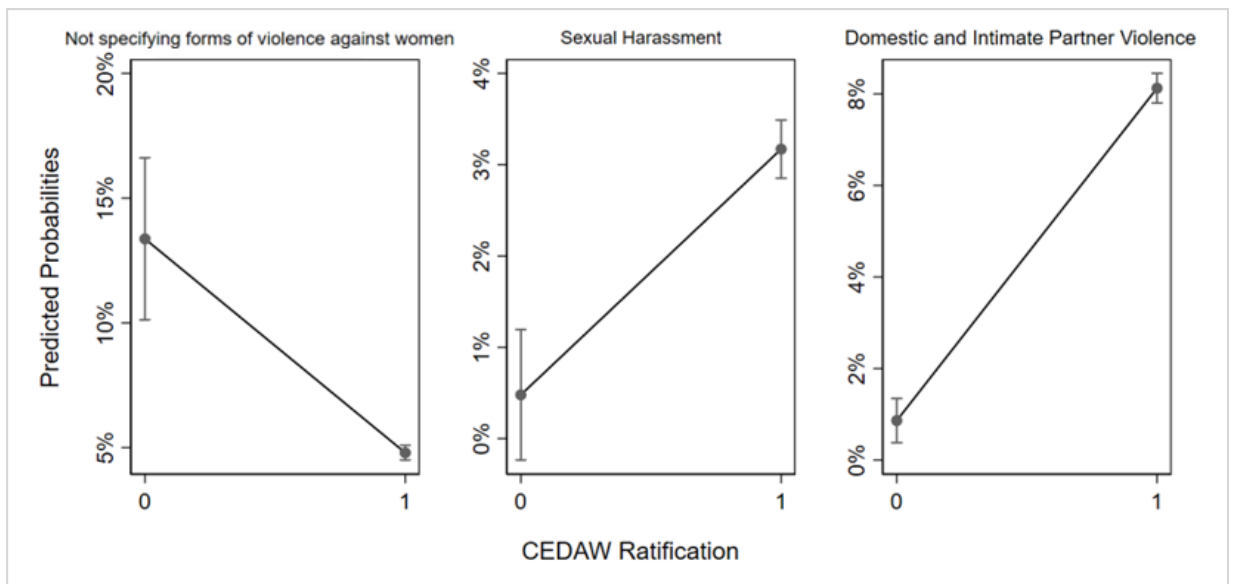

Note: The predicted probabilities of the diffusion of policies are estimated while all other control variables are held at their observed values. 95\% confidence intervals are presented with the point estimates. 
To see whether the substantive effects of CEDAW Ratification are significant or not, I estimate predicted probabilities. Figure 3 shows the predicted probabilities of adoption of policies by the three types of violence in which the coefficients of CEDAW Ratification are statistically significant.

The left panel of Figure 3 presents that the predicted probability of adopting laws without specific terms for targeted forms of violence against women is $13.368 \%$ when a country does not ratify CEDAW. The probability decreases to $4.798 \%$. On the contrary, in terms of the probability of adopting laws addressing sexual harassment, the predicted probability increases from $0.479 \%$ to $3.170 \%$. Lastly, according to the right panel, the ratification of CEDAW increases the predicted probability of introducing laws about domestic and intimate partner violence from $0.865 \%$ to $8.124 \%$. It indicates that the influence of CEDAW Ratification is not only statistically significant, but also substantially meaningful, which is consistent with my theoretical expectation.

Given that geographical contiguity or proximity, and shared colonial traditions have been studied as potential factors expediting the diffusion of policy and law (Bricker \& LaCombe 2021; Elkins, Guzman, \& Simmons 2006), I estimate pooled event history models with additional dyadic control variables including Geographical Contiguity and Same Colonial Heritage (see Table A. 2 in Appendix) to isolate the influence of the ratification of CEDAW on the adoption of violence against women laws. ${ }^{7}$ Even after the geographical contiguity and colonial heritage of country ${ }_{i}$ and country ${ }_{j}$ are controlled, the empirical results from Table A.2 in Appendix are similar to the findings from Table 2. Furthermore, the combined fixed and random effects for the influence of CEDAW Ratification and the changes in predicted probabilities of the adoption of violence against women laws are not substantially different from the results presented in Figure 2 and Figure 3 (see Table A.3 and Figure A.1 in Appendix).

\footnotetext{
7 Geographical Contiguity is a binary variable. 1 is assigned to the country ${ }_{i}$ and country dyadic $_{j}$ observations when country ${ }_{i}$ and country ${ }_{j}$ share the land or sea borders. Otherwise, $o$ is assigned. The Direct Contiguity Data (version 3.2) developed by the Correlates of War Project is employed to build this variable. In addition, Same Colonial Heritage is also a binary variable. I assign 1 to the country ${ }_{i}$ and

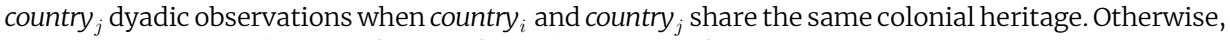
I assign o. Based on the classification from the Quality of Government dataset (Teorell et al. 2018), colonial origins are divided into 10 categories (Dutch, Spanish, Italian, the U.S., British, French, Portuguese, Belgian, British-French, and Australian).
} 


\section{ROBUSTNESS CHECK}

Table 3. Split-Sample Estimations by Types of Violence

\begin{tabular}{|c|c|c|c|c|}
\hline & $\begin{array}{c}\text { Model } 5 \\
\text { Violence } \\
\text { Against Women }\end{array}$ & $\begin{array}{c}\text { Model } 6 \\
\text { Trafficking }\end{array}$ & $\begin{array}{c}\text { Model } 7 \\
\text { Sexual } \\
\text { Harassment }\end{array}$ & $\begin{array}{c}\text { Model } 8 \\
\text { Domestic and } \\
\text { Intimate }\end{array}$ \\
\hline \multicolumn{5}{|l|}{ Independent Variable } \\
\hline \multirow[t]{2}{*}{ CEDAW Ratification } & $-1.208^{* * *}$ & $0.480^{*}$ & $1.939^{*}$ & $2.388^{* * *}$ \\
\hline & $(0.166)$ & $(0.191)$ & $(0.774)$ & $(0.292)$ \\
\hline \multicolumn{5}{|l|}{ Control Variables } \\
\hline \multirow[t]{2}{*}{ GDP per capita } & -0.060 & $0.102^{* * *}$ & $0.356^{* * *}$ & $0.083^{* * *}$ \\
\hline & $(0.037)$ & $(0.024)$ & $(0.066)$ & $(0.024)$ \\
\hline \multirow[t]{2}{*}{ Polity 2} & $0.060^{* * *}$ & $0.017^{*}$ & $0.034^{*}$ & $0.073^{* * *}$ \\
\hline & $(0.010)$ & $(0.008)$ & $(0.017)$ & $(0.007)$ \\
\hline \multirow[t]{2}{*}{ Level of Violence (MEPV) } & $0.205^{* * *}$ & $0.084^{* *}$ & 0.061 & $0.089^{* * *}$ \\
\hline & $(0.020)$ & $(0.030)$ & $(0.039)$ & $(0.018)$ \\
\hline \multirow[t]{2}{*}{ Colonial Heritage } & 0.205 & -0.126 & $-0.979 * * *$ & $-0.224^{* *}$ \\
\hline & $(0.124)$ & $(0.109)$ & $(0.174)$ & $(0.076)$ \\
\hline \multirow[t]{2}{*}{ Women in Parliaments (\%) } & $0.016^{* * *}$ & 0.001 & 0.011 & $0.015^{* * *}$ \\
\hline & $(0.004)$ & $(0.004)$ & $(0.006)$ & $(0.003)$ \\
\hline \multirow[t]{2}{*}{ Women's CSO Participation } & $0.355^{* * *}$ & -0.002 & $0.339 * * *$ & $0.298^{* * *}$ \\
\hline & $(0.058)$ & $(0.053)$ & $(0.093)$ & $(0.042)$ \\
\hline \multirow[t]{2}{*}{ CEDAW (\%) } & $0.094^{*}$ & $0.209^{* * *}$ & 0.043 & 0.028 \\
\hline & $(0.038)$ & $(0.043)$ & $(0.045)$ & $(0.021)$ \\
\hline \multirow[t]{2}{*}{ Diff. GDP per capita } & 0.007 & -0.019 & 0.038 & $-0.034^{*}$ \\
\hline & $(0.027)$ & $(0.021)$ & $(0.038)$ & $(0.017)$ \\
\hline \multirow[t]{2}{*}{ Diff. Polity 2} & 0.009 & -0.005 & 0.004 & 0.005 \\
\hline & $(0.008)$ & $(0.006)$ & $(0.015)$ & $(0.006)$ \\
\hline \multirow[t]{2}{*}{ Constant } & -11.874 & -63.618 & $-4.660^{*}$ & $-4.740^{* * *}$ \\
\hline & $(13.311)$ & $(48.959)$ & (2.103) & $(1.410)$ \\
\hline Legal System Dummy & Yes & Yes & Yes & Yes \\
\hline Time Polynomials & Yes & Yes & Yes & Yes \\
\hline Number of Observations & 19425 & 19034 & 12256 & 27958 \\
\hline AIC & 6942.867 & 7806.862 & 3087.728 & 13406.268 \\
\hline $\mathrm{BIC}$ & 7092.479 & 7956.087 & 3228.590 & 13562.799 \\
\hline Chi-Square Statistics & 633.670 & 292.982 & 189.020 & 1261.006 \\
\hline Log Likelihood & -3452.434 & -3884.431 & -1524.864 & -6684.134 \\
\hline
\end{tabular}

Note: ${ }^{*} p<0.05,{ }^{* *} p<0.01,{ }^{* * *} p<0.001$. Robust standard errors in parentheses. Akaike Information Criterion (AIC), Bayesian Information Criterion (BIC), and Log-Likelihood are presented for model comparisons. Only four separate event history models with statistically significant point estimates of CEDAW Ratification are presented here. See Table A.4 in Appendix for the results from the other four separate event history models. 
To examine whether the empirical results are sensitive to model specifications or not, I estimate separate event history models by the types of violence. Consistent with empirical results from pooled event history models, the ratification of CEDAW does not have a statistically significant relationship with the adoption of laws penalizing stalking, sexual violence, FGM, and child, early, and forced marriage. Also, in line with the results in Table 2 and Figure 3, the ratification of CEDAW increases the log-odds of adopting laws about sexual harassment, and domestic and intimate partner violence. Even though not presented, the substantive effects of the ratification of CEDAW in terms of predicted probabilities are also similar to the effects presented in Figure 3.

It is worth noting that the estimated coefficient of CEDAW Ratification is statistically significant at the level of $\mathrm{p}<0.05$ in Model 6 when the dependent variable is the adoption of laws penalizing trafficking. This result is expected because the CEDAW committee drafted the General Recommendation on trafficking of women and girls. However, empirical results from this article only give partial supports for the influence of CEDAW Ratification on the adoption of laws concerning trafficking, given that it is not statistically significant in Figure 3 based on estimates from the pooled event history model. The predicted probabilities of adopting laws about trafficking increase from 3.624\% to 5.687\%.

The empirical results from Table 2 and Table 3 are also consistently robust in other models with various combinations of control variables, in models with independent and control variables lagged by one to five years, and in models with country fixed effects.

There are also some exemplary real-world cases supporting the relationship between the ratification of CEDAW and the adoption of violence against women laws, meaning that the empirical results on the influence of the ratification of CEDAW on the adoption of violence against women laws are not the artifacts of statistical analysis. For instance, according to the combined second and third periodic report of $\mathrm{Nepal}^{8}$, the representative of Nepal admitted that the role of CEDAW to legal reforms combating domestic violence and that of women's social mobilization empowered during the implementation of CEDAW are crucial to draft bill on domestic violence by referring other countries already with domestic violence laws. Moreover, South Africa's Domestic Violence Act 116 of 1998 and Criminal Law Amendment Act 32 of 2007 concerning sexual harassment refers to CEDAW in its preamble, indicating that CEDAW provided profound

\footnotetext{
${ }^{8}$ For more information on the periodic report, please refer the following link: https://www.un.org/wo menwatch/daw/cedaw/cedaw25years/content/english/CONCLUDING_COMMENTS/Nepal/Nepal-CO-23.pdf (Accessed on November 23, 2021).
} 
information about such laws and played an important role to the adoption of such laws concerning domestic violence and sexual harassment laws in South Africa. 9 In addition, CEDAW has fostered the adoption and diffusion of domestic violence laws in the Republic of Korea, and anti-trafficking laws in Moldova and Ukraine (UNCHR, n.d.).

\section{DISCUSSION AND CONCLUSION}

Although some previous studies argue that international treaties on human rights are not consequential to improve human rights conditions in individual countries (Hafner-Burton \& Tsutsui 2007; Neumayer 2005), the Convention on the Elimination of All Forms of Discrimination Against Women appears to be one of the most efficient international human rights treaties to promote women's rights and integrity. However, along with the potential heterogeneous impacts, the impacts of CEDAW on the diffusion of laws addressing violence against women among countries have not been empirically examined thoroughly.

To fill this academic lacuna, by estimating pooled event history models and separate split-sample models, this article provides robust empirical evidence for the conducive impacts of the ratification of CEDAW on the diffusion of laws targeting sexual harassment, and domestic and intimate partner violence. In addition, despite the sensitivity to model specifications, I find that the adoption of laws penalizing trafficking of women and girls. Given that the empirical analysis in this article is based on unprecedentedly large time-series cross-national data on 129 countries from 1908 to 2016, the external generalizability of those findings is also not limited.

The academic contribution of this article is two-fold. On the one hand, it empirically demonstrates that human rights international treaties can engender legal reforms in member countries. Over decades, the quantitative literature generally argues that individual countries' policies promoting human rights including women's rights remain unchanged even after countries join series of human rights international treaties because of "problem with compliance" (Adams \& Kang 2007; Hill Jr \& Watson 2019; Hillebrecht 2012; Htun \& Weldon 2012 ). Considering that a wide array of case studies supports the consequential influence of CEDAW on the progressive policy changes for human rights, this

\footnotetext{
${ }^{9}$ For more information on the legislations enacted in South Africa and the role of CEDAW, please refer the following link: https://www2.ohchr.org/english/bodies/cedaw/docs/AdvanceVersions/CEDAW.C.ZAF.Q 4.Add1.pdf (Accessed on November 23, 2021).
} 
academic discrepancy is surprising. The empirical findings from this article reconcile such discrepancy by showing that the influence of the ratification of CEDAW on legal reforms might be heterogeneous across policies with different goals.

On the other hand, this article contributes to the literature on the diffusion of policies by demonstrating that intra-countries variables are relatively more important than inter-country variables such as the differences in the levels of economic development and democracies among countries. Thus, the empirical results from this article emphasize the importance of analyzing intra-country variables to explain variations in the diffusion of policies across the globe.

However, as all other empirical studies, this article is not completely flawless. Most importantly, considering the nature of the large-N statistical approach, this article only tests hypotheses, not the proposed mechanisms themselves. Even though this article provides some real-world examples of the proposed mechanisms, the mechanisms should be more closely examined. In addition, the influence of the ratification of CEDAW on the adoption of ground-level policies according to the various forms of violence against women could not be examined due to the lack of time-series cross-national data on the information about the actual implementation of laws. Lastly, this article does not fully differentiate between CEDAW and the General Recommendations of CEDAW given the high degree of compliance of member countries to the recommendations.

Thus, one of the natural directions of future research is to examine the association between the ratification of CEDAW and the adoption of ground-level policies addressing violence against women with more developed data. Furthermore, investigating the exact mechanisms behind the conducive impacts of the ratification of CEDAW on the adoption of policies about sexual violence and domestic and intimate partner violence with case study or comparative small-N approaches will be promising. In addition, empirical replication of this study by theorizing the different impacts of CEDAW treaty itself and the General Recommendations of CEDAW concerning violence against women on the diffusion of laws and policies concerning violence against women is plausible. 


\section{REFERENCES}

Adams, M., \& Kang, A. 2007. Regional advocacy networks and the protocol on the rights of women in Africa. Politics \& Gender 3(4), 451-474.

Allison, P. 2012. When can you safely ignore multicollinearity. Statistical horizons 5(1), 1-2.

Alter, K. J. 2000. The European Union's legal system and domestic policy: spillover or backlash? International Organization 54(3), 489-518.

Baldwin, E., Carley, S., \& Nicholson-Crotty, S. 2019. Why do countries emulate each others' policies? A global study of renewable energy policy diffusion. World Development 120, 29-45.

Benedek, W., Kisaakye, E. M., \& Oberleitner, G. 2002. Human Rights of Women: International Instruments and African Experiences.

Berry, F. S., \& Berry, W. D. 1990. State Lottery Adoptions as Policy Innovations: An Event History Analysis. American Political Science Revew 84(2), 395-415.

Betz, T., Fortunato, D., \& O’BRIEN, D. Z. 2021. Women's Descriptive Representation and Gendered Import Tax Discrimination. American Political Science Review 115(1), 307-315.

Boehmke, F. J. 2009a. Approaches to Modeling the Adoption and Diffusion of Policies with Multiple Components State Politics \& Policy Quarterly 9(2), 229-252.

Boehmke, F. J. 2009b. Policy Emulation or Policy Convergence? Potential Ambiguities in the Dyadic Event History Approach to State Policy Emulation. The Journal of Politics 71(3), 1125-1140.

Bolt, J., Robert Inklaar, jong, H. d., \& Zaden, J. L. v. (2018). Rebasing 'Maddison': new income comparisons and the shape of long-run economic development.

Bond, J. E. 2014. CEDAW in sub-Saharan Africa: Lessons in implementation. Mich. St. L. Rev., 241.

Brandt, M., \& Kaplan, J. A. 1995. The tension between Women's rights and religious rights: reservations to Cedaw by Egypt, Bangladesh and Tunisia. Journal of Law and Religion 12(1), 105-142.

Bricker, C., \& LaCombe, S. 2021. The ties that bind us: The influence of perceived state similarity on policy diffusion. Political Research Quarterly 74(2), 377-387.

Byrnes, A. C. 1989. The other human rights treaty body: The work of the Committee on the Elimination of Discrimination Against Women. Yale J. Int'1 L. 14, 1. 
Byrnes, A. C., \& Freeman, M. 2012. The impact of the CEDAW convention: Paths to equality. UNSW Law Research Paper.

Carey, H. F. 2002. The postcolonial state and the protection of human rights. Comparative Studies of South Asia, Africa and the Middle East 22(1), 59-75.

Carter, D. B., \& Signorino, C. S. 2010. Back to the future: Modeling time dependence in binary data. Political Analysis 18(3), 271-292.

Coppedge, Michael, Gerring, J., Knutsen, C. H., Lindberg, S. I., Skaaning, S.-E., . . . Ziblatt., D. (2018). "V-Dem Codebook v8" Varieties of Democracy (V-Dem).

Creamer, C. D., \& Simmons, B. A. 2018. The dynamic impact of periodic review on women's rights. Law \& Contemp. Probs. 81(4), 31-72.

Creamer, C. D., \& Simmons, B. A. 2020. The proof is in the process: self-reporting under international human rights treaties. American Journal of International Law 114(1), 1-50.

Elkins, Z., Guzman, A. T., \& Simmons, B. A. 2006. Competing for capital: The diffusion of bilateral investment treaties, 1960-2000. International Organization 60(4), 811-846.

Englehart, N. A. 2014. CEDAW and gender violence: an empirical assessment. Mich. St. L. Rev., 265-280.

Englehart, N. A., \& Miller, M. K. 2014. The CEDAW effect: international law's impact on women's rights. Journal of Human Rights 13(1), 22-47.

Evatt, E. 2002. Finding a voice for women's rights: The early days of CEDAW. Geo. Wash. Int'l L. Rev. 34(3), 515-553.

Farhoumand-Sims, C. 2009. CEDAW and Afghanistan. Journal of International Women's Studies 11(1), 136-156.

Fourie, E. 2014. Model students: Policy emulation, modernization, and Kenya's Vision 2030. African Affairs 113(453), 540-562.

George, R. 2020. The Impact of international human rights law ratification on local discourses on rights: The case of CEDAW in Al-Anba reporting in Kuwait. Human Rights Review 21(1), 43-64.

Gilardi, F. 2010. Who Learns from What in Policy Diffusion Processes? American Journal of Political Science 54(3), 650-666.

Gilardi, F. 2012. Transnational Diffusion: Norms, Ideas, and Policies. Los Angeles, CA: SAGE.

Gilardi, F., \& Füglister, K. 2008. Empirical modeling of policy diffusion in federal states: the dyadic approach. Swiss Political Science Review 14(3), 413-450.

Goyal, N. 2021. Policy Diffusion Through Multiple Streams: The (Non-) Adoption 
of Energy Conservation Building Code in India. Policy Studies Journal. Gray, M. M., Kittilson, M. C., \& Sandholtz, W. 2006. Women and globalization: A study of 180 countries, 1975-2000. International Organization 60(2), 293-333.

Hafner-Burton, E. M., \& Ron, J. 2009. Seeing double: Human rights impact through qualitative and quantitative eyes. World Politics 61(2), 360-401.

Hafner-Burton, E. M., \& Tsutsui, K. 2007. Justice lost! The failure of international human rights law to matter where needed most. Journal of Peace Research 44(4), 407-425.

Haggard, S., \& Kaufman, R. 2008. Democracy, Development and Welfare States: Latin America, East Asia, and Eastern Europe. In: Princeton, NJ: Princeton University Press.

Hair, J. F. 2009. Multivariate data analysis: Prentice Hall.

Hasunuma, L. (2019). Beyond formal representation: Case studies of women's participation in civil society in Japan. Paper presented at the Women's Studies International Forum.

Hellum, A. 2021. CEDAW AND GLOBAL STANDARDS FOR WOMEN'S RIGHTS. International Women's Rights Law and Gender Equality: Making the Law Work for Women.

Hellum, A., \& Aasen, H. S. 2013. Women's human rights: CEDAW in international, regional and national law. Cambridge University Press.

Herawan, W. N., \& Sihotang, N. 2021. Adoption of the Plea Bargaining Concept to Improve Judicial Efficiency During the Covid-19 Outbreak. Law Research Review Quarterly 7(2), 135-152.

Hill Jr, D. W. 2010. Estimating the effects of human rights treaties on state behavior. The Journal of Politics 72(4), 1161-1174.

Hill Jr, D. W., \& Watson, K. A. 2019. Democracy and compliance with human rights treaties: The conditional effectiveness of the Convention for the Elimination of All Forms of Discrimination against Women. International Studies Quarterly 63(1), 127-138.

Hillebrecht, C. 2012. Implementing international human rights law at home: Domestic politics and the European court of human rights. Human Rights Review 13(3), 279-301.

Htun, M., \& Weldon, S. L. 2012. The civic origins of progressive policy change: Combating violence against women in global perspective, 1975-2005. American Political Science Review 106(3), 548-569.

Hunt, K., \& Gruszczynski, M. 2019. The ratification of CEDAW and the liberalization of abortion laws. Politics \& Gender 15(4), 722-745.

Inglehart, R. 1997. Modernization and Postmodernization: Cultural, Economic 
and Political Change in 43 Societies. Princeton, NJ: Princeton University Press.

Inglehart, R., Norris, P., \& Ronald, I. 2003. Rising tide: Gender equality and cultural change around the world: Cambridge University Press.

Kalandadze, K., \& Orenstein, M. A. 2009. Electoral Protests and Democratization Beyond the Color Revolutions. Comparative Political Studies 42(11), 1403-1425.

Keck, M. E., \& Sikkink, K. 1998. Transnational advocacy networks in the movement society. In The social movement society: Contentious politics for a new century (pp. 217-238): Rowman and Littlefield Publishers.

Kreitzer, R., \& Boehmke, F. J. 2016. Modeling Heterogeneity in Pooled Event History Analysis. State Politics \& Policy Quarterly 16(1), 121-141.

Linos, K. 2013. The democratic foundations of policy diffusion: How health, family, and employment laws spread across countries: Oxford University Press.

Makse, T., \& Volden, C. 2011. The role of policy attributes in the diffusion of innovations. The Journal of Politics 73(1), 108-124.

Marshall, M. G. (2017a). Major episodes of political violence (MEPV) and conflict regions, 1946-2016.

Marshall, M. G. 2017b. Measuring Qualities of Governance in Complex Societal Systems: The Polity Series. APSA-CD 15(2), 5 and 8-12.

McQuigg, R. J. 2007. The responses of states to the comments of the CEDAW Committee on domestic violence. The International Journal of Human Rights 11(4), 461-479.

McQuigg, R. J. 2017. The cedaw Committee and Gender-Based Violence against Women: General Recommendation No. 35. International Human Rights Law Review 6(2), 263-278.

Meseguer, C. 2005. Policy learning, policy diffusion, and the making of a new order. The Annals of the American Academy of Political and Social Science 598(1), 67-82.

Meseguer, C., \& Gilardi, F. 2009. What is new in the study of policy diffusion? Review of International Political Economy 16(3), 527-543.

Neumayer, E. 2005. Asylum recognition rates in Western Europe: Their determinants, variation, and lack of convergence. Journal of Conflict Resolution 49(1), 43-66.

Nguyen, A. 2014. Through the Eyes of Women? the Jurisprudence of the CEDAW Committee. Outskirts 30.

O'Hara, C., \& Clement, F. 2018. Power as agency: A critical reflection on the measurement of women's empowerment in the development sector. 
World Development 106, 111-123.

Oludare, A. (2020). The Retention of Colonial Laws Against African Women. In The Routledge Handbook on Africana Criminologies (pp. 110-119): Routledge.

Pacheco, J. 2012. The Social Contagion Model: Exploring the Role of Public Opinion on the Diffusion of Antismoking Legislation across the American States. The Journal of Politics 74(1), 187-202.

Qureshi, S. 2020. The recognition of violence against women as a violation of human rights in the United Nations system. South Asian Studies 28(1), 187-198.

Reingold, B. 2008. Women as office holders: Linking descriptive and substantive representation. Political women and American democracy 9, 128-147.

Reingold, B., Kreitzer, R., Osborn, T., \& Swers, M. L. 2021. Anti-abortion Policymaking and Women's Representation. Political Research Quarterly 74(2), 403-420.

Resnik, J. 2012. Comparative (in) equalities: CEDAW, the jurisdiction of gender, and the heterogeneity of transnational law production. International journal of constitutional law 10(2), 531-550.

Shinohara, C. 2008. Global pressure, local results: the impact of CEDAW on working women in Japan. Journal of Workplace Rights 13(4).

Shipan, C. R., \& Volden, C. 2008. The Mechanisms of Policy Diffusion. American Journal of Political Science 52(4), 840-857.

Simmons, B. A. 2009. Mobilizing for human rights: international law in domestic politics: Cambridge University Press.

Simonovic, D. 2014. Global and regional standards on violence against women: the evolution and synergy of the CEDAW and Istanbul Conventions. Human Rights Quaterly 36(3), 590-606.

Stoffels, R. A. 2019. The role of the CEDAW Committee in the implementation of public policies on gender issues: analysis through a study of the protection of girls' rights in Spain. The International Journal of Human Rights 23(8), 1317-1336.

Swaine, A. 2018. Conflict-related violence against women: Transforming transition: Cambridge University Press.

Teorell, J., Dahlberg, S., Holmberg, S., Rothstein, B., Alvarado, N., \& Svensson, P. R. (2018). The Quality of Government Standard Dataset.

True, J. 2016. Explaining the global diffusion of the Women, Peace and Security agenda. International Political Science Review 37(3), 307-323.

True, J. (2018). The political economy of post-conflict violence against women. In Handbook on the International Political Economy of Gender: Edward 
Elgar Publishing.

Upreti, M., \& Jacob, J. 2018. The Philippines' Criminal Restrictions on Abortion and the CEDAW Committee's Role in Strengthening Calls for Reform. Canadian Woman Studies 33(1-2), 231-237.

UNCHR, n.d. CEAW in your daily life.Accessed at https://www.ohchr.org/EN/HRBodies/CEDAW/Pages/DailyLife.aspx (November 24, 2021).

Vijeyarasa, R. 2021. Quantifying CEDAW: Concrete Tools for Enhancing Accountability for Women's Rights. Harvard Human Rights Journal 34, $37-80$.

Volden, C. 2006. States as Policy Laboratories: Emulating Success in the Children's Health Insurance Program. American Journal of Political Science 50(2), 294-312.

Volden, C. 2016. Failures: Diffusion, Learning, and Policy Abandonment. State Politics \& Policy Quarterly 16(1), 44-77.

Weiss, A. M. 2003. Interpreting Islam and women's rights: Implementing CEDAW in Pakistan. International Sociology 18(3), 581-601.

Weldon, S. L. 2006. Inclusion, solidarity, and social movements: The global movement against gender violence. Perspectives on Politics 4(1), 55-74.

Wilensky, H. L. 1974. The welfare state and equality: Structural and ideological roots of public expenditures: Univ of California Press.

Woo, B.-D. 2021. Women's Descriptive Representation Facilitates the Adoption and Implementation of Laws Relating to Violence Against Women: Evidence from Asian Countries. Asian Women 37(2), 1-33.

Zada, S. Q. 2021. Legislative, institutional and policy reforms to combat violence against women in Afghanistan. Indian Journal of International Law 59(1), 257-283.

Zwingel, S. 2005. From intergovernmental negotiations to (sub) national change: A transnational perspective on the impact of CEDAW. International Feminist Journal of Politics 7(3), 400-424.

Zwingel, S., \& Zwingel. 2016. Translating International Women's Rights: Springer. 


\section{APPENDIX}

Table A.1. Full Table for The Combined Fixed and Random Effects in Figure 2

\begin{tabular}{ccccc}
\hline & \multicolumn{4}{c}{ The Combined Fixed and Random Effects } \\
& \multicolumn{2}{c}{ for the Influence of CEDAW by Forms of Violence } \\
\hline Forms of Violence & Point Estimate & Std. Err. & \multicolumn{2}{c}{$95 \%$ C.I. } \\
Violence against Women & -0.531 & 0.264 & -1.049 & -0.012 \\
Trafficking & 0.293 & 0.284 & -0.265 & 0.850 \\
Stalking & 0.624 & 0.623 & -0.597 & 1.846 \\
Sexual Violence & 0.128 & 0.277 & -0.415 & 0.672 \\
Sexual Harassment & 1.554 & 0.461 & 0.650 & 2.458 \\
FGM & 0.513 & 0.477 & -0.422 & 1.448 \\
Domestic and Intimate & 2.031 & 0.327 & 1.390 & 2.673 \\
Child Early Forced Marriage & 0.788 & 0.577 & -0.344 & 1.919 \\
\hline
\end{tabular}

Note: Point estimates in Bold indicate that the point estimates are statistically significant with the $95 \%$ confidence intervals. 
Table A.2. Estimations from Pooled Event History Models with Additional Dyadic Control Variables

\begin{tabular}{|c|c|c|c|}
\hline & Model A.1 & Model A.2 & Model A.3 \\
\hline \multicolumn{4}{|l|}{ Independent Variable } \\
\hline \multirow[t]{2}{*}{ CEDAW Ratification } & $0.823^{* * *}$ & $0.815^{* * *}$ & $0.820 * * *$ \\
\hline & $(0.225)$ & $(0.225)$ & $(0.225)$ \\
\hline \multicolumn{4}{|l|}{ Control Variables } \\
\hline \multirow[t]{2}{*}{ GDP per capita } & 0.025 & $0.043^{* * *}$ & 0.024 \\
\hline & $(0.013)$ & $(0.012)$ & $(0.013)$ \\
\hline \multirow[t]{2}{*}{ Polity 2} & $0.028 * * *$ & $0.032^{* * *}$ & $0.028^{* * *}$ \\
\hline & $(0.004)$ & $(0.004)$ & $(0.004)$ \\
\hline \multirow[t]{2}{*}{ Level of Violence (MEPV) } & $0.095^{* * *}$ & $0.100^{* * *}$ & $0.094^{* * *}$ \\
\hline & $(0.010)$ & $(0.010)$ & $(0.010)$ \\
\hline \multirow[t]{2}{*}{ Colonial Heritage } & $-0.125^{* *}$ & $-0.100^{*}$ & $-0.128^{* *}$ \\
\hline & $(0.044)$ & $(0.044)$ & $(0.044)$ \\
\hline \multirow[t]{2}{*}{ Women in Parliaments (\%) } & $0.012^{* * *}$ & $0.013^{* * *}$ & $0.012^{* * *}$ \\
\hline & $(0.002)$ & $(0.002)$ & $(0.002)$ \\
\hline \multirow[t]{2}{*}{ Women's CSO Participation } & $0.266^{* * *}$ & $0.277^{* * *}$ & $0.265^{* * *}$ \\
\hline & $(0.024)$ & $(0.024)$ & $(0.024)$ \\
\hline \multirow[t]{2}{*}{ CEDAW (\%) } & $0.171^{* * *}$ & $0.171^{* * *}$ & $0.171^{* * *}$ \\
\hline & $(0.007)$ & $(0.007)$ & $(0.007)$ \\
\hline \multirow[t]{2}{*}{ Diff. GDP per capita } & -0.008 & -0.009 & -0.009 \\
\hline & $(0.010)$ & $(0.010)$ & $(0.010)$ \\
\hline \multirow[t]{2}{*}{ Diff. Polity 2} & -0.005 & -0.004 & -0.005 \\
\hline & $(0.003)$ & $(0.003)$ & $(0.003)$ \\
\hline \multirow[t]{2}{*}{ Geographical Contiguity } & $0.748^{* * *}$ & & $0.825^{* * *}$ \\
\hline & $(0.081)$ & & $(0.126)$ \\
\hline \multirow[t]{2}{*}{ Same Colonial Heritage } & & $0.529^{* * *}$ & $0.516^{* * *}$ \\
\hline & & $(0.082)$ & $(0.127)$ \\
\hline \multirow[t]{2}{*}{ Constant } & $-6.431^{* * *}$ & $-6.998 * * *$ & $-6.457^{* * *}$ \\
\hline & $(1.628)$ & $(1.555)$ & $(1.622)$ \\
\hline \multirow[t]{2}{*}{ var(CEDAW Ratification) } & $0.404^{*}$ & $0.404^{*}$ & $0.404^{*}$ \\
\hline & $(0.194)$ & $(0.195)$ & $(0.194)$ \\
\hline \multirow[t]{2}{*}{ var(constant) } & $23.294^{*}$ & $20.987^{*}$ & $23.085^{*}$ \\
\hline & $(10.826)$ & $(9.766)$ & $(10.734)$ \\
\hline Legal System Dummy & Yes & Yes & Yes \\
\hline Time Polynomials & Yes & Yes & Yes \\
\hline Number of Observations & 113065 & 113065 & 113065 \\
\hline AIC & 41276.790 & 41319.037 & 41264.135 \\
\hline $\mathrm{BIC}$ & 41479.140 & 41521.388 & 41458.121 \\
\hline Chi-Square Statistics & 1828.845 & 1766.822 & 1829.638 \\
\hline Log Likelihood & -20617.395 & -20638.519 & -20617.068 \\
\hline
\end{tabular}

Note: ${ }^{*} \mathrm{p}<0.05,{ }^{* *} \mathrm{p}<0.01,{ }^{* * *} \mathrm{p}<0.001$. Robust standard errors in parentheses. Akaike Information Criterion (AIC), Bayesian Information Criterion (BIC), and Log-Likelihood are presented for model comparisons. 
Table A.3. The Combined Fixed and Random Effects based on the Results from Table A.2

\begin{tabular}{|c|c|c|c|c|}
\hline \multirow{4}{*}{$\begin{array}{c}\text { Forms of Violence } \\
\text { Violence against Women }\end{array}$} & \multicolumn{4}{|c|}{$\begin{array}{l}\text { The Combined Fixed and Random Effects } \\
\text { for the Influence of CEDAW by Forms of Violence }\end{array}$} \\
\hline & \multicolumn{4}{|c|}{ Model A.1 } \\
\hline & \multirow{2}{*}{$\begin{array}{l}\text { Point Estimate } \\
-0.517\end{array}$} & \multirow{2}{*}{$\begin{array}{l}\text { Std. Err. } \\
0.263\end{array}$} & \multicolumn{2}{|c|}{ 95\% C.I. } \\
\hline & & & -1.032 & -0.002 \\
\hline Trafficking & 0.316 & 0.283 & -0.239 & 0.870 \\
\hline Stalking & 0.660 & 0.616 & -0.548 & 1.868 \\
\hline Sexual Violence & 0.160 & 0.276 & -0.380 & 0.700 \\
\hline Sexual Harassment & 1.582 & 0.458 & 0.685 & 2.479 \\
\hline FGM & 0.523 & 0.476 & -0.410 & 1.457 \\
\hline Domestic and Intimate & 2.039 & 0.325 & 1.401 & 2.676 \\
\hline \multirow[t]{2}{*}{ Child Early Forced Marriage } & 0.820 & 0.572 & -0.301 & 1.942 \\
\hline & \multicolumn{4}{|c|}{ Model A.2 } \\
\hline Forms of Violence & Point Estimate & Std. Err. & \multicolumn{2}{|c|}{ 95\% C.I. } \\
\hline Violence against Women & -0.519 & 0.263 & -1.034 & -0.004 \\
\hline Trafficking & 0.310 & 0.283 & -0.245 & 0.865 \\
\hline Stalking & 0.650 & 0.616 & -0.558 & 1.859 \\
\hline Sexual Violence & 0.151 & 0.276 & -0.390 & 0.692 \\
\hline Sexual Harassment & 1.571 & 0.458 & 0.673 & 2.468 \\
\hline FGM & 0.512 & 0.476 & -0.421 & 1.446 \\
\hline Domestic and Intimate & 2.028 & 0.326 & 1.390 & 2.667 \\
\hline \multirow[t]{2}{*}{ Child Early Forced Marriage } & 0.809 & 0.572 & -0.312 & 1.930 \\
\hline & \multicolumn{4}{|c|}{ Model A.3 } \\
\hline Forms of Violence & Point Estimate & Std. Err. & \multicolumn{2}{|c|}{ 95\% C.I. } \\
\hline Violence against Women & -0.524 & 0.263 & -1.035 & -0.009 \\
\hline Trafficking & 0.313 & 0.283 & -0.242 & 0.867 \\
\hline Stalking & 0.657 & 0.616 & -0.551 & 1.866 \\
\hline Sexual Violence & 0.157 & 0.276 & -0.383 & 0.697 \\
\hline Sexual Harassment & 1.579 & 0.458 & 0.682 & 2.476 \\
\hline FGM & 0.520 & 0.476 & -0.413 & 1.454 \\
\hline Domestic and Intimate & 2.036 & 0.326 & 1.398 & 2.674 \\
\hline Child Early Forced Marriage & 0.817 & 0.572 & -0.305 & 1.939 \\
\hline
\end{tabular}

Note: Point estimates in Bold indicate that the point estimates are statistically significant with the 95\% confidence intervals. 
The Heterogeneous Impacts of the Ratification of CEDAW on the Adoption of Violence Against Women Lawes | 373

Figure A.1. Predicted Probabilities of the Adoption of Violence Against Women Laws by Types of Violence based on the Results from Table A.3

(a) Model A.1
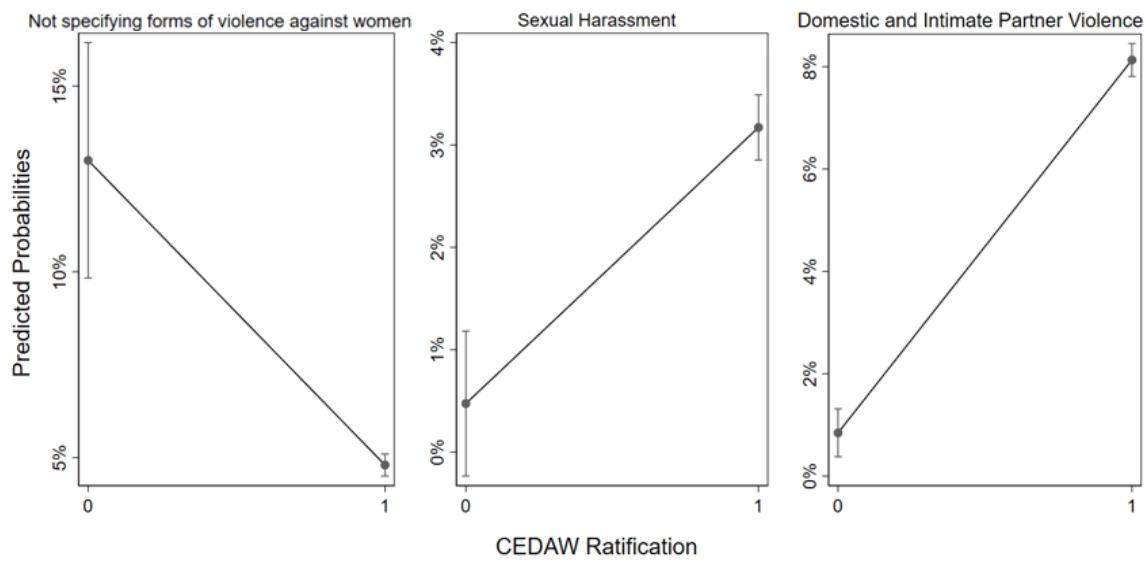

(b) Model A.2
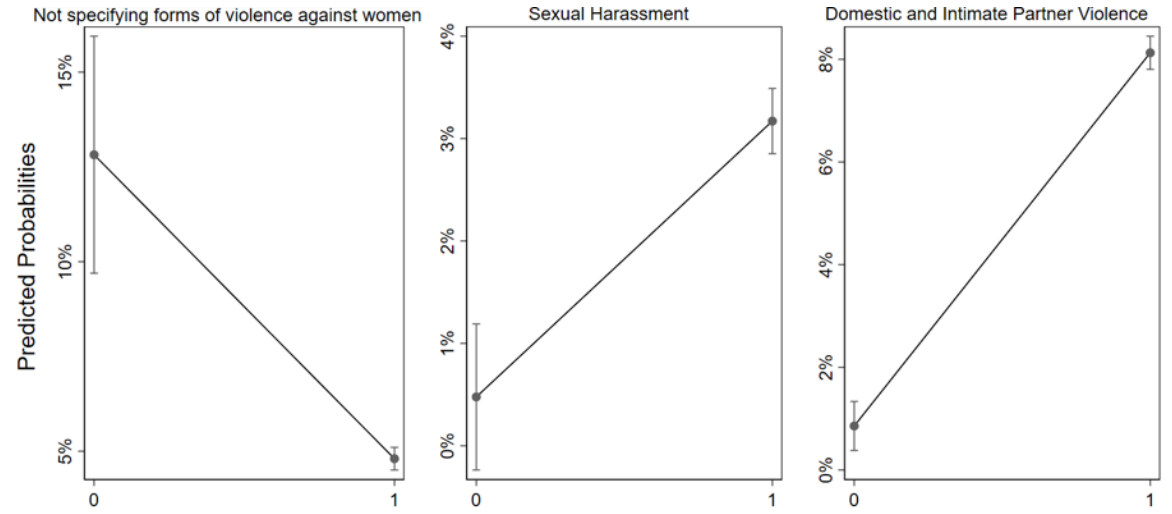
The Korean Joumal of International Studies 19-3 | 374

(c) Model A.3
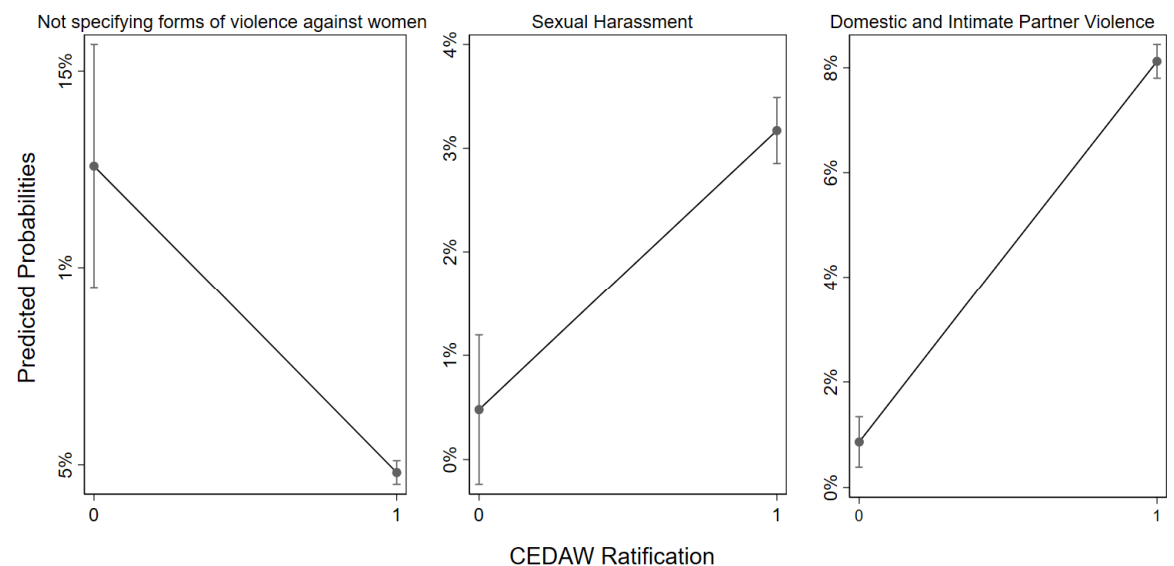

Note: The predicted probabilities of the diffusion of policies are estimated while all other control variables are held at their observed values. $95 \%$ confidence intervals are presented with the point estimates. 
Table A.4. Split-Sample Estimations by the Other Four Types of Violence

\begin{tabular}{|c|c|c|c|c|}
\hline & $\begin{array}{c}\text { Model A.4 } \\
\text { Stalking }\end{array}$ & $\begin{array}{c}\text { Model A.5 } \\
\text { Sexual } \\
\text { Violence }\end{array}$ & $\begin{array}{c}\text { Model A.6 } \\
\text { FGM }\end{array}$ & $\begin{array}{c}\text { Model A.7 } \\
\text { Child Early } \\
\text { Forced } \\
\text { Marriage }\end{array}$ \\
\hline \multicolumn{5}{|l|}{ Independent Variable } \\
\hline \multirow[t]{2}{*}{ CEDAW Ratification } & 0.422 & 0.116 & 0.876 & 2.509 \\
\hline & (1.198) & $(0.177)$ & $(0.554)$ & $(1.917)$ \\
\hline \multicolumn{5}{|l|}{ Control Variables } \\
\hline \multirow[t]{2}{*}{ GDP per capita } & -0.224 & -0.047 & 0.055 & 0.015 \\
\hline & $(0.225)$ & $(0.037)$ & $(0.078)$ & $(0.131)$ \\
\hline \multirow[t]{2}{*}{ Polity 2} & 0.086 & -0.001 & -0.061 & -0.095 \\
\hline & $(0.104)$ & $(0.009)$ & $(0.049)$ & $(0.087)$ \\
\hline \multirow[t]{2}{*}{ Level of Violence (MEPV) } & $0.295^{*}$ & $0.174^{* * *}$ & 0.008 & -0.100 \\
\hline & $(0.122)$ & $(0.021)$ & $(0.086)$ & $(0.111)$ \\
\hline \multirow[t]{2}{*}{ Colonial Heritage } & $-1.783^{* *}$ & 0.080 & -0.513 & -0.065 \\
\hline & $(0.636)$ & $(0.116)$ & $(0.356)$ & $(0.437)$ \\
\hline \multirow[t]{2}{*}{ Women in Parliaments (\%) } & $0.067^{*}$ & $0.017^{* * *}$ & -0.022 & -0.011 \\
\hline & $(0.029)$ & $(0.004)$ & $(0.013)$ & $(0.015)$ \\
\hline \multirow[t]{2}{*}{ Women's CSO Participation } & 0.276 & $0.448^{* * *}$ & 0.315 & $0.814^{* * *}$ \\
\hline & $(0.384)$ & $(0.059)$ & $(0.167)$ & $(0.238)$ \\
\hline \multirow[t]{2}{*}{ CEDAW (\%) } & -0.017 & $0.019 * * *$ & $0.054^{* * *}$ & $0.052^{* *}$ \\
\hline & $(0.033)$ & $(0.003)$ & $(0.010)$ & $(0.017)$ \\
\hline \multirow[t]{2}{*}{ Diff. GDP per capita } & 0.261 & 0.021 & 0.061 & -0.090 \\
\hline & $(0.169)$ & $(0.025)$ & $(0.067)$ & $(0.101)$ \\
\hline \multirow[t]{2}{*}{ Diff. Polity 2} & -0.097 & 0.000 & -0.017 & 0.044 \\
\hline & $(0.102)$ & $(0.008)$ & $(0.022)$ & $(0.027)$ \\
\hline \multirow[t]{2}{*}{ Constant } & 38.863 & $134.027^{* * *}$ & -14.124 & $-5.907^{* *}$ \\
\hline & $(66.511)$ & $(25.992)$ & $(39.257)$ & $(1.932)$ \\
\hline Legal System Dummy & Yes & Yes & Yes & Yes \\
\hline Time Polynomials & Yes & Yes & Yes & Yes \\
\hline Number of Observations & 3821 & 19846 & 5930 & 4795 \\
\hline AIC & 259.230 & 6908.894 & 1032.299 & 558.445 \\
\hline $\mathrm{BIC}$ & 367.812 & 7058.913 & 1152.679 & 681.476 \\
\hline Chi-Square Statistics & 31.539 & 496.970 & 67.871 & 48.549 \\
\hline Log Likelihood & -3452.434 & -3435.447 & -498.150 & -260.222 \\
\hline
\end{tabular}

Note: ${ }^{*} p<0.05,{ }^{* *} p<0.01,{ }^{* *} p<0.001$. Robust standard errors in parentheses. Akaike Information Criterion (AIC), Bayesian Information Criterion (BIC), and Log-Likelihood are presented for model comparisons. 